McKee K, Muir J \& Moore T (2017) Housing policy in the UK: the importance of spatial nuance. Housing Studies, 32 (1), pp. 60-72. https://doi.org/10.1080/02673037.2016.1181722.

This is an Accepted Manuscript of an article published by Taylor \& Francis Group in Housing Studies on 2 May 2016, available online: http://www.tandfonline.com/10.1080/02673037.2016.1181722. 


\title{
Housing Policy in the UK: the importance of spatial nuance
}

\begin{abstract}
The UK has been engaged in an ongoing process of constitutional reform since the late 1990s, when devolved administrations were established in Northern Ireland, Scotland and Wales. As devolution has evolved there has been a greater trend towards divergence in housing policy, which calls into question any notion of a 'UK experience'. Whilst the 2014 Scottish independence referendum again returned constitutional reform high onto the political agenda, there still remain tensions between devolved governments and the UK government in Westminster, with England increasingly becoming the outlier in policy terms. Informed by ideas of social constructionism, which emphasises the politics of housing, this paper draws on an analysis of policy narratives to highlight the need for greater geographical sensitivity. This requires not only more spatial nuance, but also a recognition that these differences are underpinned by divergent political narratives in different parts of the UK. This emphasis on the politics underpinning policy has relevance internationally in other geographical contexts.
\end{abstract}

Keywords: devolution, constitutional change, Scottish referendum, welfare reform, social constructionism 


\section{Introduction}

Despite media headlines about 'UK Housing Policy' (see Guardian 2016, 2014; Financial Times 2016) housing policy has been a devolved matter since 1999. Prior to the establishment of the devolved administrations in Northern Ireland, Scotland and Wales separate laws and regulatory frameworks existed across the UK. Consequently, this paper asserts there is no such thing as a 'UK experience' in the housing field, and advocates for more 'spatially-aware' policy analysis (Pinch 1997) that avoids conflating the English experience with that of the UK as a whole. Building on past research about the devolved nature of public policy making (see for example, Paris et al 2003; Sim 2004; Pawson 2006; McKee and Phillips 2012; Muir 2013; Maclennan and O'Sullivan 2013) this paper seeks to update and advance our understanding of these issues by focusing on the period post 2010 . As the 2014 Scottish independence referendum and subsequent calls for further UK constitutional reform highlight, devolution is not a one off event rather an ongoing, evolving process. These arguments have international reach given similar debates about sub-state nationalism and self-determination are occurring in other places such as Chile, Spain and Canada. Moreover, by locating our arguments within a wider body of literature on social constructionism and interpretative governance (Jacobs et al 2004; Bevir and Rhodes 2006), we seek to draw attention to the politics of housing, adding to international debates within Housing Studies (Jacobs and Pawson 2015).

The structure of our paper is as follows. The first section briefly traces the piecemeal, evolving nature of devolution in the UK and how this has influenced the shifting dynamic of power between governments and territories. The second section draws attention to differences in policy narratives through a focus on the policy examples of social and affordable housing, and regulation of the private rented sector (PRS). The third and final substantive section draws on the UK government's welfare reform agenda to highlight 
tensions in the devolved settlement, and the way in which divergent political narratives are an important consideration in any analysis of political devolution. Through an emphasis on the different policy and political contexts across the UK we aim to develop a more complex and critical understanding of devolution as an ongoing process (Pollitt 2013).

\section{Devolution: a piece-meal and ongoing process}

The devolution of legislative powers across the UK was a defining moment of the Blair administration. An integral aspect of New Labour's modernisation agenda (Newman 2001), it has left a long-lasting legacy, fundamentally altering the 'institutional landscape of public policy in the UK' (MacKinnon 2015: 48). In general terms, devolution involves the transfer of political and/or legislative powers previously exercised by national parliaments to a subordinate, subnational elected body, often defined on a geographical basis (Bogdanor 1999).

Elected assemblies, and an associated set of devolved powers, were introduced to Scotland, Wales and Northern Ireland in 1998, following referenda in each case. These new legislative bodies all sat for the first time in 1999. Devolved powers include major areas of public policy such as housing, planning, education, health and regeneration in all four jurisdictions. Reserved powers include most taxation, social security (except Northern Ireland $^{1}$ ), defence, energy, immigration and constitutional matters (for fuller discussion see, Keating 2002; MacKinnon 2015). This division of responsibilities reflected the functions that were already being exercised by the Northern Irish, Scottish and Welsh Offices. There was no 'equivalent tradition' of administrative devolution in England, which is why the UK government assumed responsibility for English functions, and why there was no wider reform of the UK constitution (Jeffrey 2007: 93). 
The form of devolution in each nation has therefore been varied from the outset, including the initial financial settlement and powers. ${ }^{2}$ It has continued to evolve differently depending on the political context and degree of public support:

- Scotland: $74 \%$ voted in favour of a Scottish Parliament, with $64 \%$ also in favour of tax-raising powers (McGuinness 2012). Unlike with the other assemblies, power to introduce an increase in income tax was granted in 1998, but has never been used. Further tax powers were introduced in 2012, and a referendum on Scottish independence in 2014 resulted in 55\% wishing to remain part of the UK. The Smith Commission (2014), convened following the referendum, argued for the further devolution of powers, including changes to borrowing powers and to social security benefits: an issue returned to in section three. The Scotland Act 2016, which recently gained royal assent, addressed some of these recommendations.

- Wales: Just over 50\% voted in favour of a Welsh Assembly in 1999 (McGuinness 2012). The National Assembly for Wales was not given legislative responsibility, however it received a wide range of administrative powers as listed previously. In 2011 in a second referendum, 64\% supported the introduction of law-making powers for the Welsh Assembly, now the Welsh Government. Further proposals for devolution (HMSO 2015b) have been critiqued due to concerns over the funding to support the proposed new powers, and the difficulties of implementing a reserved powers model in Wales (Jones 2015).

- Northern Ireland (NI): 71\% voted in favour of devolution as part of a wider referendum on the Good Friday agreement in 1998 (McGuinness 2012). Devolution was part of a peace settlement to try and bring the NI troubles to an end. The structure proved initially unstable and the Assembly did not sit between 2002 and 2007. 
- England: it does not have its own devolved government; instead, the UK government in Westminster legislates for both English and UK policy. Dissatisfaction with this constitutional arrangement has been long-standing, as captured by Dalyell's 'West Lothian' question (Bogdanor 1999). It has been further heightened since the Scottish referendum as reflected in calls for 'English Vote for English Laws' (EVEL) (Jeffrey et al 2014), and a resurged interest in devolution for English cities. This builds on the decentralisation to regional offices of government, creation of the London Mayor, and regional development agencies initiated under New Labour in the 1990s (Humphrey and Shaw 2004; Maclennan and O’Sullivan 2013). New Labour's plan for elected regional assemblies was shelved after the first referendum in the North East in 2004 indicated 78\% were against the proposal (McGuinness 2012).

Since 1999, devolution has continued to evolve, in part due to the 'piecemeal' and 'uneven' processes by which it was introduced in the first instance (Jeffrey 2007: 100). Devolution is fundamentally a geographical process, involving the rescaling and remaking of governance, and thus the creation of new political geographies (Brenner 2004; MacKinnon 2015) and 'state spaces' (Clifford and Morphet 2015a: 4). This lends credence to Peck's (2001: 449) argument that the state is best conceived not as a monolithic, static entity; rather as a 'process in motion'.

UK devolution is asymmetrical with differences in powers, responsibilities and fiscal autonomy not only between the UK government and the devolved administrations, but also between the four nations. As Jeffrey comments the UK is an increasingly 'lopsided' state, in which England is the larger, more dominant partner demographically and economically, but also the only part to be governed centrally by the Westminster Parliament (2007: 95). This uneven balance, in terms of the institutions of government, is further exacerbated by different UK political parties being in power in different tiers of government, for example the election 
in 2015 of a Conservative government, and the election of an SNP government in Scotland in 2011, and the involvement of parties without a UK-wide remit, especially in NI. Processes of devolution therefore need to be situated and understood within the context of this wider and varied political environment. As well as fundamental differences between political parties, the changing economic context and implementation of austerity measures also marks a shift in the wider political context between the early and latter periods of devolution (Danson et al 2012; MacKinnon 2015). This is where the literature on interpretive governance and social constructionism can be insightful (Jacobs et al 2004; Bevir and Rhodes 2006), providing an important theoretical backdrop to understanding tensions and constraints in the UK constitutional settlement; points that will be returned to in section three.

\section{Policy and Political Narratives across the UK}

Compared to other devolved states, the UK model can be regarded as highly 'permissive' (Jeffrey 2007: 103). The, way in which the devolved administrations are funded through the block grant (devised through the Barnett formula) means their funding is not tied to delivering UK policy ambitions, although goals may of course be tempered by UK Treasury financial constraints and other policy areas reserved to Westminster, such as taxation and social security benefits. These tensions in part explain why there is much continuity in housing (and wider social) policies across the UK. This is more evident in some policy areas than others, as has been well documented in past research on devolution. For example, longstanding policies to promote homeownership through various types of shared equity and shared ownership initiatives, most recently Help to Buy (Wilcox et al 2015); housing stock transfer as a solution to 'modernizing' social housing under the Blair administration (Pawson et al 2010); and an emphasis on social landlords (primarily housing associations) 'wider role' 
in supporting community development and regeneration in their communities, as embodied in 'Big Society' debates under the coalition (2010-15) government (McKee 2015b).

In the period post-2010, it is in housing policies to support those on low incomes and/or in rental housing that breaks and fractures in the underpinning political narratives, and subsequent policies, become more evident. This is reverberated in wider social policy, as evident in debates about welfare reform (Mooney and Scott 2011). These areas of discord are more illuminating in understanding the underpinning politics as well as the social construction of particular policy narratives. For this reason, we have concentrated our focus in this paper on social and affordable housing, including the Right to Buy policy, and regulation of the PRS. ${ }^{3}$ A final important point to consider is MacKinnon's (2015) call to also think about divergence within as well as between nations. Whilst space constrains the extent to which we can explore this, we nonetheless endorse his argument to also think temporally about policy shifts within a territory. This argument is particularly pertinent in the English context. Recent proposals to support further devolution to English cities through Growth Deals and City Deals, and the proposed creation of Mayors outside of London are good examples of this desire for greater autonomy and policy differentiation within a country.

In the remainder of this section, we focus on two areas of housing policy: social and affordable housing, including the Right to Buy, and regulation of the PRS. We argue that in the latter phase of devolution since 2010 England has increasingly become the outlier in policy terms with clear political differences emerging between UK and devolved government's approaches to housing for low-income and vulnerable groups. This reflects vastly different interpretations of the causes and solutions to poverty and inequality, as well as the appropriate role and size of the state (McKee 2015a). For example, whilst Conservative governments have been informed by individualistic explanations (e.g. 
behavioural arguments), devolved governments have drawn influence from more structuralist accounts (e.g. unemployment, welfare reform).

As Table 1 highlights, the housing tenure structure varies geographically with social housing being a larger sector in Scotland than elsewhere in the UK. Whilst devolved governments retain a positive commitment to social housing (Scottish Government 2010, 2011; Welsh Assembly Government 2010; Department for Social Development 2012), recognising its vital role as a welfare safety-net and a vehicle to achieve policy commitments on affordable housing, in England the sector has come under attack by a Conservative government that has problematised it as a cause of poverty (Jacobs and Manzi 2013; Hodkinson and Robbins 2014). The Localism Act 2011 effectively ended security of tenure for social housing tenants in England through introducing shorter 'flexible tenancies' (typically for two to five years), and introducing higher 'affordable rents', which are more aligned to local market rents. This is in contrast to continued security of tenure and belowmarket subsidised rents elsewhere in the UK. In Scotland local authorities continue to receive subsidy to build council housing with many engaging in small annual programmes, in addition to new developments by housing associations.

\section{[Insert Table 1 here]}

Whilst devolved governments continue to invest significantly in social housing, the policy rhetoric in England has shifted much more explicitly to 'affordable housing' with a greater emphasis on subsidising home-ownership, particularly for first-time-buyers. Social housing by contrast has been denigrated and marginalised in England. In his closing speech of the 2015 Conservative Party conference the Prime Minister advocated relaxing planning 
laws that require developers to build social housing as part of a mixed-tenure private developments, so that more homes for sale can be built, and public investment shifted towards home buying (Independent 2015; HMSO 2016). Whilst policies to promote homeownership (such as Help to Buy) exist across the UK, a dual approach that recognises the importance of social housing predominates outwith England, with affordable housing imagined more broadly as comprising (social) homes for rent as well as homes for sale:

We are committed to a flexible, efficient and responsive housing system that helps people to meet their housing needs. Nearly 1 in 3 households rent their home from a local authority, a housing association or a private landlord. We want people to be able to move between different types of housing - renting social housing, renting from a private landlord, and buying a home - as needs and situations change (Welsh Government 2014, no page number).

[the Housing Strategy] is an inclusive vision that seeks to address housing need across all tenures and to play a role in helping support and sustain economic recovery, create employment and regenerate some of our most deprived and neglected communities [...] we must ensure that good quality housing is available, in every tenure, which is affordable, accessible and sustainable (Department for Social Development 2012: 3).

This is not the case in England, of which the recent Housing and Planning Bill 201516 is a good example. It continues the measures introduced by the Localism Act relating to security of tenure, with new English secure tenancies to be 'for a fixed term of between 2 and 5 years' (HMSO 2016: 50), thus further undermining tenant's ability to make a 'home for life'. The Bill also proposes higher rents for higher income tenants. This 'pay to stay' provision, which aims to restrict social housing to those on the lowest income (2016: 28), 
imagines social housing as a welfare safety-net for those on the lowest incomes. These measures move English social housing policy in a fundamentally different direction to the rest of the UK, continuing the problematisation and denigration of social housing (Hancock and Mooney 2013; Jacobs and Manzi 2013). Affordable housing for sale is the UK government's main response to the 'housing crisis' in England. As outlined in the aforementioned Bill a relaxation of planning obligations to build social housing in new developments, coupled with the vigorous promotion of the Help to Buy scheme which reduces the deposit requirement of prospective homeowners, are to be the main policy vehicles by which this has been achieved. The political and policy rhetoric in England is therefore very much geared towards homeownership, assuming this is the tenure everyone 'aspires' too. This approach reflects the Conservative Party's positioning of itself as the 'party of home ownership' (Conservative Party 2015: 53-54; see also, HMSO 2016).

To achieve this goal the UK Government are to extend the Right to Buy in England: a long-standing policy which enables sitting council tenants to buy their home at heavily discounted rates, to housing association tenants. Introduced in the 1980s the Right to Buy was a significant driver for the growth of homeownership in the UK, especially amongst lower-income groups. It has been critiqued for leading to the residualisation and denigration of social housing as a 'tenure of last resort' (Forrest and Murie 1988). These news plans provoked a split in the housing association movement in England with the National Housing Federation offering a voluntary deal to the government, with the proviso any affordable homes lost would be replaced (HMSO 2015a). However these associations are to be compensated by the sale of high-value local authority stock. This policy reflects not simply a desire to maximise homeownership, but also to reduce the total level of social housing stock. This is distinct to affordable housing agendas elsewhere in the UK. 
Whilst housing association tenants in the devolved nations already have the Right to Buy the specific rules vary, with funding also arranged differently to the English proposals. Moreover, in Scotland it has now been abolished by the Housing (Scotland) Act 2014. From August 2016 social housing tenants will no longer have the right to buy their home. This different approach reflects a recognition of the positive value of social housing in Scotland, and the importance of retaining affordable homes for rent in order to meet broader policy goals in relation to creating a more equal Scottish society (Scottish Government 2015b). Right to Buy discounts were already restricted prior to this via the Housing (Scotland) Act 2001, which sought to balance the competing interests of current and future tenants. There are also plans to abolish the Right to Buy in Wales (Welsh Government 2015). Northern Ireland has reduced discounts in recent years but also extended its House Sales Scheme to housing association tenants in 2003. There are no plans to abolish the Right to Buy.

The final example we will explore is in relation to the regulation of the PRS. The sector has doubled in size over the last fifteen years, with the growth more pronounced in England where it has overtaken social housing as the largest rental sector (see Table 1). It has also become the second largest tenure in Northern Ireland. Traditionally associated with students and mobile young professionals the PRS is now much more diverse, housing growing numbers of young adults, families with children, and low-income households. This shift reflects difficulties in accessing both social housing and homeownership, as well as broader patterns of austerity which have impacted negatively on incomes and wage levels (McKee et al 2015).

In October 2015 the Scottish Government published the Private Housing (Tenancies) Bill, which became an Act in March 2016. It seeks to modernise the PRS via the following proposals: 
- Streamlined, model tenancy agreements which are easier to understand and contain modernised grounds for repossession, with notice periods linked to length of tenancy;

- Ending of the 'no fault' grounds for possession;

- Rent increases limited to one per year with three months' notice, with local authorities having scope to implement rent controls in areas where there is concern;

- More progressive repossession grounds for rent arrears;

These reforms reflect concerns about the inability of people to make a 'home' in the PRS, and the impact this in turn has on their well-being (Shelter Commission on Housing and Wellbeing 2015). It has been paralleled by political commitments to boost supply in both the private homeownership sector and social housing.

Northern Ireland and Wales have also sought to reform the PRS through the Housing (Wales) Act 2014 and the Landlord Registration Scheme Regulations (Northern Ireland) 2014. These Acts require landlords to be registered and licensed with their details held on a central database; it also affords local authorities enforcement powers to ensure compliance with these requirements. It mirrors the landlord registration scheme that has been in operation in Scotland since 2013, introduced by the Private Rented Housing (Scotland) Act 2011. In Northern Ireland, the Houses in Multiple Occupation (HMO) Act 2016 makes comprehensive provision for better conditions in HMOs, including an HMO licensing system in line with the rest of the UK, to replace the current failing landlord registration scheme. By contrast there is no appetite for even this level of centralised state regulation in England; instead it is left to local authority discretion to create and implement registration schemes resulting in considerable divergence. Not least as local government budget pressures mean there is little resource for enforcement action. Consequently, PRS tenants in England are much more vulnerable to landlords unwilling or unable to fulfil their responsibilities. This political faith of the UK government in market-based solutions to the housing crisis, coupled 
with reforms to the Housing Benefit system which limit the amount of financial support households can receive, has resulted in low-income households being displaced from neighbourhoods where rents are more expensive (Hamnett 2010, 2014).

What these two policy examples highlight is that whilst the Celtic nations increasingly draw lessons from each other, England is increasingly out of sync with policy debates elsewhere in the UK. Differences in the political leanings of the UK and devolved administrations is a key factor, for they have fundamentally opposing views on the causes and solutions to poverty, and the role of the state in mitigating inequality. ${ }^{4}$ This not only leads to policy differentiation, but also tensions in the devolved settlement as the next section explores.

\section{Tensions in the Devolved Settlement}

Policy development across the UK is 'heavily dependent on, and closely interrelated with, the dynamics of devolution' (Mooney and Scott 2011: 6). Whilst most commenters distinguish between devolved and reserved powers (see section one), Gibb (2015: 29) argues that housing policy is best understood as a 'hybrid' of the two. This is because key housing policy levers and social security provisions continue to be reserved to the UK government in Westminster (with the exception of Northern Ireland, as previously discussed). Whilst in other devolved or federal states (e.g. Belgium, Canada and the USA) national and subnational tiers of government have more shared responsibility for raising and distributing fiscal revenue, in the UK context the level of funding allocated to devolved administrations stems from decisions made at Westminster. As Jeffrey (2007: 101) highlights this creates 'spillover effects', with the effects of decisions taken in London passed on to the other nations. The devolved governments therefore have to manage the fall-out from the UK government's particular (political) approach to managing the fiscal deficit that emerged after 
the global economic crisis of 2008. This creates tensions when devolved administrations, and their electorates, adopt a different position on public spending and priorities.

Housing Benefit (HB) is a strong policy example of these inherent (political) tensions within the devolution settlement. It is a social security benefit designed to help low-income households meet their rental costs (in both social and private rental housing). Given the shift from supply to demand side housing subsidies and the 'demunicipalisation' of council housing since the 1980s, HB occupies a pivotal role in housing policy. Yet it remains a reserved power of the UK government, again with the exception of Northern Ireland. A large component of welfare spending, it has become a target for reform under both UK Coalition and Conservative governments since 2010 (Jacobs and Manzi 2013; Beatty et al 2014; Powell 2015). The deep nature of these cuts, and their disproportionate impact upon low income groups has exacerbated pre-existing tensions between the UK and devolved administrations.

The reforms introduced multiple changes in HB provisions: the 'bedroom tax', which reduced claimants payment if they were deemed to have more bedrooms than they needed; a raising of the age limit for the Shared Accommodation Rate from 25 to 35, which means young people will only receive help with their rent for costs equivalent to living in shared HMO accommodation; and a reduction of the level of Local Housing Allowance for PRS tenants, which introduces a cap on the maximum payment that can be received in line with rents in the bottom 30 per cent within the local area. Combined these measures mean households are increasingly having to meet the gap between their actual rent and their HB payment. Moreover, HB is set to become part of the new Universal Credit, which will amalgamate all social security payments into one monthly payment, with a maximum monthly cap regardless of where people live (an important factor given geographical differences in rental costs). It has still to be fully rolled out across the UK, although it has been piloted in specific areas. 
The Scottish Government's response to HB reforms was to use Discretionary Housing Payments (DHPs) to mitigate the worst impacts of the 'Bedroom Tax', and indeed, the SNP pre-referendum promised to abolish the controversial policy in an independent Scotland. HB was also a key focus of the Smith Commission (2014), although arguably the recommendations did not deliver the degree of control some political parties and civic organizations would have liked (for good summary, see Gibb 2015). By contrast the Welsh Government has come under critique from its national assembly for not following the Scottish model of using DHPs; it chose instead to focus on the construction of smaller properties and investing in advice provision (National Assembly for Wales Public Accounts Committee 2015). In Northern Ireland, agreement between the five Executive coalition parties on the Conservative's welfare reform agenda has proved impossible over several years, delaying the introduction of equivalent legislation to the Welfare Reform Act 2012. Welfare reform was one of several issues addressed in the recent 'Fresh Start Agreement' (Bowers et al 2015). The matter was resolved through the NI Assembly agreeing to pass responsibility for legislation back to Westminster in late 2015. The NI Executive then commissioned an academic to recommend a package of mitigating features for the next four years, which included no use of the 'bedroom' tax/ spare room subsidy, and a continuation of the current option of HB payments made directly to the landlord (Evason 2016).

As the example of HB illuminates, tensions between different tiers of governance are as much about political differences, as they are about institutional and legal arrangements. This is underlined only too clearly in the divergent narratives and discourses underpinning welfare reform agendas. 


\section{Conclusion}

The UK is not a unitary state, rather a 'family of nations' (Sturgeon, cited in Clifford and Morphet 2015b: 58). It is therefore vital to avoid conflating the English experience with that of the UK. Instead a more spatially nuanced policy analysis that recognises discontinuity as well as continuity, within and between territories is needed. Housing has been a 'prominent part of the devolution story' and a site of much 'policy innovation' in the UK context (Gibb 2015: 39). In this latter period of devolution from 2010 onwards England has increasingly become the outlier, diverging significantly in housing policy terms from the rest of the UK. As such, it is unhelpful and misleading to talk about 'UK housing policy'. Not least as the 2014 Scottish Independence Referendum, subsequent debates about EVEL and the impending EU referendum continue to pose further questions about the future of the union, with the issue of separation never disappearing entirely from political debates.

Furthermore, this paper aims to highlight the emergence of 'new state spaces' following the re-territorialisation of policy that occurred after the devolved administrations were established in 1998. This re-scaling of public policy making is fundamentally geographical, and demands a more spatially nuanced understanding of the evolving process of devolution. This can only be achieved, we argue, by situating housing policy within the wider political context and the shifting nature of party politics in the UK. Tensions between different tiers of government go beyond institutional and legal arrangements; they reflect fundamental political understandings of inequality and the role of the state in mitigating this. This has increased in the latter phase of devolution from 2010 onwards as tensions have been exacerbated, in part, due to these aforementioned political differences. Our argument seeks to connect an emphasis on policy context and political differences with the changing role of the British state. In doing so however, we look to interpretive understandings of governance (Bevir and Rhodes 2006), which draw attention to the underpinning narratives, political 
projects and social constructed nature of policy. This paper therefore connects to the longstanding body of work in Housing Studies influenced by social constructionist perspectives (see for example, Jacobs et al 2004).

To conclude, there is no such thing as the 'UK experience' in contemporary housing policy, if indeed there ever was. This has been evidenced with reference to examples from social and affordable housing, and regulation of the PRS. The policy discussions within this paper have further resonance beyond the UK, not least as devolution is an international phenomenon and critical aspect of contemporary governance. This paper seeks to add to these broader debates through an updated, and critically informed exploration of the UK context. In doing so, we seek to contribute to recent international debates within Housing Studies about the importance of engaging with the politics of housing (see Special Issue edited by Jacobs and Pawson 2015).

\section{Endnotes}

1. Northern Ireland's 'parity' agreement on social security is that the Assembly's power to legislate will be used to deliver the same system (including benefit rates) in recognition of the common personal taxation provisions that exist across the UK. Any additional costs of an enhanced system (for example the measures agreed in 2016) must be met from the block grant (Bowers et al 2015).

2. Scotland's reserved powers are set out in legislation and all other powers are assumed to be devolved; Northern Ireland has both reserved and excepted powers in legislation, the latter being where laws are usually made at Westminster but can be made by the NI Assembly with the consent of the Secretary of State; Wales has a list of devolved powers known as 'Assembly Act' provisions and all other powers are assumed to be reserved (see, https://www.gov.uk/guidance/devolution-of-powers-to- 
scotland-wales-and-northern-ireland). In all cases Westminster may legislate on devolved matters with the consent of the relevant devolved body, as has happened recently with Northern Ireland's Welfare Reform Bill.

3. Whilst homelessness is another field marked by significant divergence in the UK context, these differences are long-standing and have been well documented elsewhere and so are not covered here (see for example Anderson 2004; Fitzpatrick 2004; Pawson and Davidson 2008; Wilcox and Fitzpatrick 2010; Mackie 2015).

4. Whilst the language of 'fairness' has been used in the Scottish context to emphasise the desire for a more equal Scottish society and the need for state intervention to deliver this, in England the very same language has been mobilised against lowincome groups to justify the introduction of welfare reform to tackle perceived 'welfare scroungers' (who are often counter-posed) with 'hard-working families'. These differences reflect fundamentally different understandings of the causes and solutions to poverty, and the role of state intervention (see, Mooney and Scott 2011). 
Table 1: Tenure - UK by Country (\% of People)

\begin{tabular}{|l|l|l|l|l|l|}
\hline & England & $\begin{array}{l}\text { Northern } \\
\text { Ireland }\end{array}$ & Scotland & Wales & UK \\
\hline Owner-Occupiers & 64.8 & 71.9 & 65.6 & 68.8 & $\mathbf{6 5 . 3}$ \\
\hline Social Renters & 16.5 & 12.3 & 21.5 & 15.5 & $\mathbf{1 6 . 7}$ \\
\hline Private Renters & 16.9 & 14.1 & 11.9 & 14.2 & $\mathbf{1 6 . 3}$ \\
\hline Other & 1.8 & 2.3 & 1.5 & 1.5 & $\mathbf{1 . 8}$ \\
\hline
\end{tabular}

Source: 2011 UK Census 


\section{References}

Anderson, I. (2004) "Housing, Homelessness and the Welfare State in the UK”, International Journal of Housing Policy 4(3): 369-389.

Beatty, C.; Brewer, M.; Browne, J.; Cole, I.; Emmerson, C.; Hood, A.; Joyce, R.; Kemp, P.; and Powell, R. (2014) The Impact of Recent Reforms to Local Housing Allowances: summary of key findings (Research Report No. 874). London: Department of Work and Pensions. Bevir, M. and Rhodes, R.A.W (2006) "Interpretive Approaches to British Government and Politics”, British Politics 1: 84-112.

Bogdanor, V. (1999) Devolution in the United Kingdom. Oxford: Oxford University Press. Brenner, N. (2004) New State Spaces: urban governance and the rescaling of statehood. Oxford: Oxford University Press.

Bowers, P., Kennedy, S., Parkin, L., Armstrong, H. and Wilson, W. (2015) A Fresh Start: the Stormont Agreement and Implementation Plan and the Northern Ireland (Welfare Reform) Bill 2015-16 [Bill 99]. Briefing Paper 7389, London: House of Commons Library.

Clifford, B. and Morphet, J. (2015a) "Introduction to Devolution and the Geography of Policy" The Geographical Journal 181(1): 2-5.

Clifford, B. and Morphet, J. (2015b) “Afterword: the Scottish Referendum, the English Question and the Changing Constitutional Geography of the United Kingdom”, The Geographical Journal 181(1): 57-60.

Conservative Party (2015) Conservative Party Manifesto:

http://issuu.com/conservativeparty/docs/ge_manifesto_low_res_bdecb3a47a0faf?e=16696947 $\underline{\text { /12362115\#search }}$

Danson, M.; MacLeod, G.; Mooney, G. (2012) “Devolution and the Shifting Political Economic Geographies of the United Kingdom", Environment and Planning C: Government and Policy 30(1) $1-9$. 
Department for Social Development (2012) Facing the Future: The Housing Strategy for Northern Ireland 2012-17. Belfast: Department for Social Development.

Evason, E. (2016) Welfare Reform Mitigations Working Group Report. Belfast: Welfare Reform Mitigations Working Group.

Financial Times (2016) Taylor Wimpey Boosted by UK Housing Policy, January 11 2016: http://www.ft.com/fastft/2016/01/11/taylor-wimpey-boosted-by-uk-housing-policy/

Forrest, R. and Murie, A. (1988) Selling the Welfare State: the privatisation of public housing. London: Routledge.

Fitzpatrick, S. (2004) “Homelessness" pp183-198, in D. Sim (ed.) (2004) Housing and Public Policy in Post-devolution Scotland. Coventry: Chartered Institute of Housing.

Gibb, K. (2015) “Housing Policy in Scotland since Devolution: divergence, crisis, integration and opportunity", Poverty and Social Justice 23(1): 29-42.

Guardian (2016) "What Cliches Tell us About the Changes to UK Housing Policy", Guardian 2 February 2016: http://www.theguardian.com/grant-thornton-partnerzone/2016/feb/02/cliches-changes-housing-policy-association-boards

Guardian (2014) “The UK's Housing Policy is Surely Madder than Venezeula's”, Guardian 14 May 2014: http://www.theguardian.com/commentisfree/2014/may/04/housing-policy$\underline{\text { madness-ed-milibands-rent-reforms-landlords-tenants }}$

Hamnett, C. (2010) "Moving the Poor Out of Central London? The Implications of the Coalition Government 2010 Cuts to Housing Benefits", Environment and Planning A 42(12): 2809-2819.

Hamnett, C. (2014) "Shrinking the Welfare State: the structure, geography and impact of British Government benefit cuts", Transactions of the Institute of British Geographers 39(4): 490-503. 
Hancock. L. and Mooney, G. (2013) “'Welfare Ghettoes’ and the 'Broken Society': territorial stigmatisation in the contemporary UK" Housing Theory and Society 30(1): 46-64.

Her Majesty’s Stationary Officer (HMSO) (2015a) “Historic Agreement Will Extend Right to Buy to 1.3 million More Tenants": https://www.gov.uk/government/news/historic-agreement$\underline{\text { will-extend-right-to-buy-to-13-million-more-tenants }}$

Her Majesty's Stationary Office (HMSO) (2015b) Draft Wales Bill. HMSO: London. Her Majesty's Stationary Office (HMSO) (2016) Housing and Planning Bill 2015-16: explanatory notes. HMSO: London.

Hodkinson, S. and Robbins, G. (2013) “The Return of Class War Conservatism? Housing under the UK Coalition Government”, Critical Social Policy 33(1): 57-77.

Humphrey, L. and Shaw (2004) "Regional Devolution and Democratic Renewal: developing a radical approach to stakeholder involvement in the English regions", Environment and Planning A 36(12): 2183-2202.

Independent (2015) “Tory Conference 2015: David Cameron’s Speech in Full”, http://www.independent.co.uk/news/uk/politics/tory-party-conference-2015-david-cameronsspeech-in-full-a6684656.html

Jacobs, K.; Kemeny, J. and Manzi, T. (2004) Social Constructionism in Housing Research. Hampshire: Ashgate.

Jacobs, K. and Manzi, T. (2013) 'New Localism, Old Retrenchment: the 'Big Society', housing policy and the policy of welfare reform", Housing Theory and Society 30(1): 29-45. Jacobs, K. and Pawson, H. (2015) "Introduction to the Special Issue: the politics of housing”, Housing Studies: DOI: 10.1080/02673037.2015.1082273 
Jones, A. (2015) “First Minister's Fresh Blast at the St David's Agreement”, Wales Online 3/3/2015: http://www.walesonline.co.uk/news/wales-news/first-ministers-fresh-blast-st$\underline{8762273}$

Jeffrey, C.; Wyn Jones, R; Henderson, A.; Scully, R.; and Lodge, G. (2014) Taking England Seriously: the new English politics:

http://www.centreonconstitutionalchange.ac.uk/sites/default/files/news/Taking\%20England\% 20Seriously_The\%20New\%20English\%20Politics.pdf

Jeffrey, C. (2007) “The Unfinished Business of Devolution: seven open questions” Public Policy and Administration 22(1): 92-108

Keating, M. (2002) "Devolution in Public Policy in the United Kingdom: divergence or convergence? pp 3-21, in J. Adams and P. Robinson (eds) Devolution in Practice: public policy differences within the UK. London: IPPR and ESRC.

MacKinnon, D. (2015) "Devolution, State Restructuring and Policy Divergence in the UK", The Geographical Journal 181(1): 47-56.

Maclennan, D. and O’Sullivan, A. (2013) “Localism, Devolution and Housing Policies”, Housing Studies, 28(4): 599-615.

Mackie, P. (2015) "Homelessness Prevention and the Welsh Legal Duty: lessons for international policies", Housing Studies 30(1): 40-59.

McGuinness, F. (2012) UK Election Statistics: 1918-2012, Research Paper 12/43, London: House of Commons Library.

McKee, K.; Moore, T. and Crawford, J. (2015) Understanding the Housing Aspirations of People in Scotland. Edinburgh: Scottish Government. 
McKee, K. and Phillips, D. (2012) "Social Housing and Homelessness Policies: reconciling social justice and social mix", pp 227-242, in G.Mooney and G.Scott (eds) $\underline{\text { Social Justice and }}$ Social Policy in Scotland. Bristol: Policy Press.

McKee, K. (2015a) (ed.) "Introduction to the Special Issue - The Big Society, Localism and Housing Policy: recasting state-citizen relations in an age of austerity”, Housing Theory and Society 32(1): 1-8.

McKee, K. (2015b) “Community Anchor Housing Associations: illuminating the contested nature of neoliberal governing practices at the local scale", Environment and Planning C 47: $1-16$.

Mooney, G. and Scott, G. (2011) "Social Justice, Social Welfare and Devolution:

Nationalism and Social Policy Making in Scotland”, Poverty and Public Policy 3(4): 1-21.

Muir, J. (2013) “The Dynamics of Policy-Making under UK Devolution: social housing in Northern Ireland", Housing Studies 28(7): 1081-1093.

National Assembly for Wales Public Accounts Committee (2015) Responding to welfare Reforms in Wales. Cardiff: Welsh Assembly.

Newman, J. (2001) Modernizing Governance: New Labour, Policy and Society. Open University: Milton Keynes.

Paris, C.; Gray, P. and Muir, J. (2003) “Devolving Housing Policy and Practice in Northern Ireland 1998-2002”, Housing Studies 18(2):159-175.

Pawson, H.; Mullins, D. and Gilmour, T. (2010) After Council Housing: Britain's social landlords. Palgrave Macmillan.

Pawson, H. and Davidson, E. (2008) "Radically Divergent? Homeless Policy and Practice in Post-devolution Scotland", International Journal of Housing Policy 8(1): 39-60. 
Pawson, H. (2006) “Restructuring England's Social Housing Sector since 1989: Undermining or Underpinning the Fundamentals of Public Housing?” Housing Studies 21(5): 767783.

Peck, J. (2001) "Neoliberalizing States: thin policies/hard outcomes", Progress in Human Geography 25(3): 445-455.

Pinch, S. (1998) "Knowledge Communities, Spatial Theory and Social Policy”, Social Policy and Administration 32: 556-71.

Pollitt, C. (ed.) (2013) Context in Public Policy and Management: the missing link? Cheltenham: Edward Elgar.

Powell, R. (2015) "Housing Benefit Reform and the Private Rented Sector in the UK: on the deleterious consequences of short-term, ideological 'knowledge'”, Housing, Theory and Society (Online Early).

Scottish Government (2015a) Private Housing (Tenancies) Bill Scotland. HMSO: Edinburgh.

Scottish Government (2015b) Creating a Fairer Scotland: what matters to you? Edinburgh: Scottish Government.

Scottish Government (2011) Homes Fit for the 21 ${ }^{\text {st }}$ Century: the Scottish Government's Strategy and Action Plan for Housing in the Next Decade: 2011-2020. Edinburgh: Scottish Government.

Scottish Government (2010) Fresh Thinking, New Ideas. Edinburgh: Scottish Government. Shelter Commission on Housing and Wellbeing (2015) A Blueprint for Scotland's Future. Commission website: http://housingandwellbeing.org/assets/documents/Commission-Final$\underline{\text { Report.pdf }}$ 
Sim, D. (ed.) (2004) Housing and Public Policy in Post-devolution Scotland. Coventry:

Chartered Institute of Housing.

Smith Commission (2014) Report of the Smith Commission for further Devolution of Powers to the Scottish Parliament. Smith Commission website: http://www.smithcommission.scot/wp-content/uploads/2014/11/The_Smith_Commission_Report-1.pdf Welsh Assembly Government (2010) Improving Lives and Communities: homes in Wales. Cardiff: WAG.

Welsh Government (2014) Renting. Welsh Government website: http://gov.wales/topics/housing-and-regeneration/housing-supply/renting/?lang=en Welsh Government (2015) Written Statement - Consultation Report on the Future of Right to Buy and Right to Acquire, Ministerial Statement, Cardiff: Welsh Government, $3^{\text {rd }}$ June 2015. http://gov.wales/about/cabinet/cabinetstatements/2015/rtbrta/?lang=en Wilcox, S.; Perry, J. and Williams, P. (2015) UK Housing Review: 2015 Briefing Paper. Coventry: Chartered Institute of Housing.

Wilcox, S. and Fitzpatrick, S. (2010) The Impact of Devolution: housing and homelessness. York: Joseph Rowntree Foundation. 